\title{
THE THEOPHORIC ELEMENT BA'AL IN ANCIENT PHOENICIAN INSCRIPTIONS
}

\author{
AURELIAN BOTICA* \\ Emanuel University of Oradea
}

\begin{abstract}
The following study analyzes the usage of the name Batal in ancient Phoenician inscriptions. The analysis starts with the premise that the deity named Batal played a major role in Canaanite religion, including the religion of the people of Israel. First of all, in order to understand correctly this phenomenon, our study sketches in broad lines the historical and religious context of the ancient Near East. Second, the study takes into account a series of corollary issues, like the concepts of "fertility" and the "Sacred Marriage", in order to obtain as clear a picture as possible of the identity and character of the god Ba?al. Third, the study focuses on a number of inscriptions from Phoenicia. A number of scholars have argued that these inscriptions represent our best evidence from Phoenicia to reconstructing the identity of Ba団al.
\end{abstract}

KEY WORDS: Ba团al, Phoenicia, Old Testament, religion, names

\section{Introduction}

There exists a fundamental distinction between the ancient Near Eastern (ANE) and the modern understanding of personal names. The contemporary mentality has rarely shown any interests outside the boundaries of family lineage or esthetic preferences. In fact, it was the rise of the Greek dualistic world view that marked the beginning of the demise of the ANE logic of continuity, where symbol and reality were not clearly distinguished. The context underlying the ANE view of the name is infinitely vast, combining elements from religion, philosophy and social life. The ancient man saw a

* AURELIAN BOTICA is Lecturer in Biblical Studies at Emanuel University of Oradea, Romania. 
very close relation between the name and the nature of the entity that was named. ${ }^{1}$ Thus:

When it is believed that the nature of a thing is comprehended in its name, then on the one hand emphasis is laid on the idea that knowledge of the name mediates a direct relationship with the nature, and on the other the name is regarded as to such an extent an expression of the individual character of its owner that it can, in fact, stand for him, become a concept interchangeable with him. ${ }^{2}$

However, in the following study we will focus not so much on the general philosophy of names in the ANE, but on the connotations carried by the name $\mathrm{Ba}$ ?al, as this appears in several of the old Phoenician inscriptions. The name Ba?al was a very familiar expression to, say, a tenth century man or woman living the land of Canaan. First, people would use the name to refer to the god Ba?al, one of the most important deities in the Ancient Near East. ${ }^{3}$ Second, the name-as a theophoric element—could be part of a person's name or could be the individual name of that person. ${ }^{4}$ Indeed, both Phoenician inscriptions and the Old Testament bear witness to this practice. ${ }^{5}$ Third, the name Ba国al could also refer to the name of a region or locality, in the sense that the god Ba?al would have been the protector of

1 Thus Eichrodt, Theology of the Old Testament (Philadelphia, PA: Westminster, 1961), 1:206ff.; 2:40ff.; Hawthorne, "Name", The International Standard Bible Encyclopedia, ISBE (Grand Rapids, MI: Eerdmans, 1986), 3:481-483.

2 Eichrodt, Theology, 2:40.

3 The Old Testament mentions the god Batal for the first time in Numbers 25:3, 5, 18, under the title $\mathrm{Ba}$ al-peor. It is possible that this deity was venerated on the summit of a mountain (see Numbers 23:28). For the relationship between Israelite and pagan names for deities see Zevit, The Religions of Ancient Israel (New York, NY: Continuum, 2001), 596

4 "Theophoric element" or "God-form" element in names. In other words, names that contain the name of God or Lord within them (e.g., Elimelech [my God is king], Eliyahu [my God is Lord]).

5 See Bright, $A$ History of Israel, 3rd ed. (Philadelphia, PA: Westminster, 1981), 241, for the name Itto'ba'al, the king of Tire, and father of Jezebeel. See also Merrill, Everlasting Dominion (Nashville, TN: Broadman, 2006), 396; Zevit, The Religions of Ancient Israel, 591ff., and Smith, The Early History of God (Grand Rapids, MI: Eerdmans, 2002), $76 \mathrm{ff}$. For Batal as a theophoric element see Ba Zal-hanan (Genesis 36:38); See 1 Chronicles 5:5, Batal, the son of Reaiah; 1 Chronicles 8:29-30; 9:36, Batal, the son of Gibeon. Perhaps the best example is the name Jerubbaal (Let Batal contend against him), that people gave Gideon when he destroyed Batal's altar (Judges 6:32). For other exam-

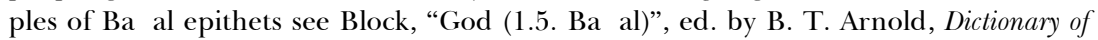
Old Testament Historical Books (Downers Grove, IL: Intervarsity Press, 2005), $341 \mathrm{ff}$.

PERICHORESIS $10.1(2012)$ 
the respective city. Invariably, in most of these cities people would build altars and worship Ba?al. ${ }^{6}$

In Phoenicia, the name Ba?al appeared in inscriptions with reference to both human and divine characters. For example, many of the inscriptions were written in order to narrate the achievements of the person buried in sarcophagi, and thus to immortalize (often appealing to the divine Batal) his or her fame for all future generations. As Schmitz noted, "with the exception of Phoenician inscriptions, all sources of information about the religion of Phoenicia are secondary". ${ }^{7}$ As we will show later, scholars have also had to take into account the earlier mythology about Ba?al from the tablets of Ugarit.

\section{Historical and Religious Background}

Geographically, Phoenicia existed along the "Syrian littoral north of Palestine", as a "conglomerate of city-states that were distinguished from adjacent areas by its preferred dealings with Indo-Europeans and Greeks". ${ }^{8}$ An important presence in the Mediterranean world, Phoenicia never achieved

Thus Stuart, "Names, Proper", ISBE, 3:484, and Kaufmann, The Religion of Israel, translated by M. Greenberg (New York: Schoken Books, 1960), 123. For examples in the Old Testament see Ba Zal-zephon (Exodus 14:9); Ba Zal-Gad, in the valley of Lebanon, bellow Mount Hermon (Joshua 11:17); Ba Zal-Shalisha (2 Kings 4:42). One may note the fact that the name Balal was not always an indication of pagan presence in Israel. As 2 Samuel 13:23 shows, certain Israelite regions could use this name even when the majority of the inhabitants were Hebrews (Ba Zal-hazor). It is nevertheless possible that names such as these might have been inherited and kept unchanged by the Israelites from pre-occupation times. See also Numbers 32:38 (Balal-meon) and Joshua 19:8 (Batalat-beer for Ramat) for occasions when the occupying Israelites did change the Canaanite names that contained the theophoric element Batal. One may also note Tigay, You Shall Have No Other Gods. Israelite Religion in the Light of Hebrew Inscriptions (Atlanta, GA: Scholars Press, 1986), 30, for the theory that, in naming certain geographical locations with the form ba 2al, some Israelites may have meant YHWH (as was the case with David in 2 Samuel 5:20).

"Phoenician Religion", The Anchor Bible Dictionary, ABD (New York, NY: Doubleday, 1922), 5:358, and Lipinsky, "The Phoenicians", ed. by J. M. Sasson, Civilizations of the Ancient Near East, 2 volumes (New York: Scribner, 1995), 2:1321-22. For the problem of deriving an account of the religious world of the Phoenicians from inscriptions see Ribichini, "Beliefs and Religious Life", ed. by S. Moscati, The Phoenicians (New York: Abbeville Press, 1989), 120ff. 
the established status of a nation. In fact, the name Phoenicia was originally given by the Greeks to the "coastal region of the eastern Mediterranean". ${ }^{9}$ The early history of the culture may go back to the fifth millennium, although the first non-biblical attestation comes from the fourteen century and it informs us about the "inhabitants of Canaan", who were "calling themselves in Akkadian Kinahu or Kinanu". ${ }^{10}$ However, the religious worldview of Phoenicia, and its impact upon Israel, were far greater than the cultural and the economic influence.

In the area of religion, the Phoenicians inherited a complex polytheistic tradition from the earlier cultures, especially from the practical and written cult of Ugarit. ${ }^{11}$ Even though the name Ba?al appeared in sources earlier than these texts, the Ugaritic worldview made a profound impact upon the neighboring cultures that followed. For example, the fourteen century Ba?al Cycle is one of the documents that laid the ground for all subsequent derivations in Ba?al theology. ${ }^{12}$ In a way, Phoenician religion is properly Canaanite. The names Ba?al, El, and Ashtoreth (with "possible" derivations to Astarte/Anat) represented three of the pillar gods of the Canaanite pantheon. As we mentioned, the gods evolved from the earlier sources of the old Akkad and Ugarit, but received names that resembled more the Canaanite pantheon. ${ }^{13}$

$9 \quad$ Lipinsky, "The Phoenicians", 2:1321.

10 Harden, The Phoenicians (New York, NY: Frederick A. Praeger, 1962), 21. Harden refers here to the Amarna letters as the first extra-biblical document to attest the Phoenician along the Mediterranean coast. For the earliest settlement found in Byblos see Bondi, "The Origins in the East", ed. by S. Moscati, The Phoenicians, 23, who refers to this "Neolithic settlement" described "as the largest of its time in the Mediterranean area".

11 One may note, however, that as a divine name, Batal appeared in sources earlier than the Ugaritic texts or inscriptions. Thus de Moor, "Ba国al", ed. by G. J. Botterweck, Theological Dictionary of the Old Testament (TDNT) (Grand Rapids, MI: Eerdmans, 1988), 2:187, for references to sources from the Old Babylonian period. The same phenomenon took place with respect to the dissemination of the name $\mathrm{El}$, which is found in texts as early as the Old Akkad; thus Baker, "God, Names of", Dictionary of the Pentateuch (Downers Grove, Il: Intervarsity Press, 2003), 360.

12 Thus Smith, "Myth and Mythmaking in Canaan and Ancient Israel", Civilizations of the Ancient Near East, 2:203 1ff.; The Ugaritic Ba Zal Cycle (Leiden: Brill, 1994/2009); The Early History of God (Grand Rapids, MI: Eerdmans, 2002), 28ff.; Liverani, "Phoenicia", $I S B E, 3: 860$, who shows that Phoenician religion was a "direct continuation of "Canaanite' religion of the Late Bronze Age (known especially from the Ugaritic texts)".

13 Liverani, "Phoenicia", ISBE, 3:861 lists, among the other deities that Phoenicians worshipped, Melqart (with the other names of Eshmun and Adonis), Resheph, Dagon, and Elyon, that were "within certain limits amenable to the fundamental elements of the 
Later influences may also be found in the names of deities such as Shadrapa, Horon, Sid and Bes. ${ }^{14}$ For the later phase of Phoenician history, scholars have traditionally relied on the reconstructed work of Philo of Byblos. His Phoenician History was partly preserved by Eusebius of Caesarea, Praeparatio Evangelica. Philo lived between 70 and 160 AD, but his work was influenced by a much earlier Phoenician historian named Sanchuniathon. According to Philo, Sanchuniathon must have lived before Hesiod and had access to older records. ${ }^{15}$

The majority of Phoenician inscriptions and artifacts reveal the fact that Ba?al became more prominent than the other deities in the everyday, religious practice of the Phoenicians. However, as various data show, the Phoenicians honored the other deities as well. For example, in the Ugarit list, El functioned as the supreme deity, the "El of the Sources", or "El the king", the begetter of all other gods. ${ }^{16}$ Many of the second millennium texts mention $\mathrm{El}$ in this position, even though the events that appear to have dramatic consequences in the life of the pantheon or in the realm of human beings involve the younger deities like Ba?al, Anat, and Astarte. ${ }^{17}$ Nevertheless, in spite of the supremacy of El within the Canaanite pantheon, Ba?al was clearly the most active, or the god who had the most practical relevance in the life of the ordinary Canaanite worshiper. ${ }^{18}$ The encounter between

triad”. See also Schmitz, "Phoenician Religion”, 5:362, and Zevit, The Religions of Ancient Israel, 608ff, for the phenomenon of "paired deities" like Elyon and Ba?alat (at Byblos), Astarte and Melqart (at Tyre), Ba?al Hammon and Tinnit (5th century Carthage), and evidently the pair Batal-Astarte.

14 Thus Day, "Canaan, Religion of", $A B D, 1: 833$.

15 Although Philo's record agrees in general with the information found in the early Phoenician inscriptions, scholars have detected a strong Hellenistic influence in his writings, especially in his cosmogonic treaties. Thus one important motif that is missing from his accounts, but which was essential to ancient Phoenician religion, is the "dying and rising god who was engaged in conflict with Mot". Nevertheless, as Baumgarten has shown in The Phoenician History of Philo of Byblos (Leiden: Brill, 1981), 96, the accounts of Philo may indeed be accurate, in spite of the Hellenistic terminology that characterizes his writings.

16 See Prichard, "Poems About Ba国al and Anath", Ancient Near Eastern Texts Relating to the Old Testament, 3rd ed. (Princeton, NJ: Princeton UP, 1969), 129-142; Smith, The Early History of God, 28, "Myth and Mythmaking", 2032; Ribichini, "Beliefs and Religious Life”, ed. by S. Moscati, The Phoenicians (New York: Abbeville Press, 1989), 122.

17 Thus Marvin Pope, El in the Ugaritic Texts (Leiden: Brill Archive, 1955), 82ff. For a critique of Pope on the role and influence of El in the Ugaritic pantheon see Gray, The Legacy of Canaan: the Ras Shamra Texts and Their Legacy to the Old Testament (Leiden: Brill Archive, 1957), 115. 
Elijah and the prophets $\mathrm{Ba}$ ?al (1 Kings 18) attest to the impact that Ba?al worship had on the people of Israel. The reason, again, had to do with the role Ba?al played in bringing fertility to the humans. For a god to command the storms that brought "rain" and the "dew" meant that he rose above any other divinity in the pantheon. According to Canaanite mythology, in the winter Batal disappeared in the underworld and all vegetation died out with him. ${ }^{19}$ Anat rescued Balal in the Spring and all crops returned to life with him. In this context, scholars have pointed out that the Phoenician sacred festivals combined "elements of agricultural and mythopoetic origin", where the motif of death and resurrection played an important role. ${ }^{20}$

Ba国al worship may have also touched on the issue of sexuality. The consort of El was Ashtoreth, the "Lady of the Sea", and the sources show that their relation involved sexual intercourse. As in other mythological accounts, it was the sexual intercourse between primordial deities that made possible the birth of all other gods. ${ }^{21}$ However, in the subsequent chapters of the myths, Batal himself becomes the partner of Anat and (later) Astarte. ${ }^{22}$ In fact, the Ugaritic Ba?al Cycle describes several encounters which involve Ba?al and a number of female characters. ${ }^{23}$ Myths such as these enforced the notion that sexual encounters among the gods impacted the fer-

19 van der Toorn, "Nine Months Among the Peasants in the Palestinian Highlands: An Anthropological on Local Religion in the Early Bronze Age", ed. by W. G. Dever Symbiosis, Symbolism, and the Power of the Past (Indiana, IN: Eisenbrauns, 2003), 393-410. For a reevaluation of the theory of the "dying and rising god" see Smith, The Origins of Biblical Monotheism (New York, NY: Oxford University Press, 2001), 104ff. See also de Moor, "Ba国al", TDOT, 2:185, for the motif of the "dying and raising god" in Phoenician religion, and Schmitz, "Phoenician Religion", $A B D, 5: 359$. a general account on the role of the gods in Creation myths see von Soden, The Ancient Orient (Grand Rapids, MI: Eerdmans, 1985), 212ff. and Walton, Ancient Israelite Culture in Its Ancient Context (Grand Rapids, MI: Zondervan, 1990), 24ff., with analysis of cosmogonies from ancient Egypt, Mesopotamia, Sumer and (later) Akkad and Canaan. See also Zevit, The Religions of Ancient Israel, 649, for the fact that archaeological data show that pair-deities are attested even in the worship of ancient Israelites. The Bible itself indicate this practice, especially in the period of the Judges and the Monarchy (e.g., Judges 6:25, with reference to "altar of Batal and the Asherah [pole] in Ghideon's family").

22 Thus de Moor, "batal", TDOT, 2:185-186. Note that in a number of Ugaritic and Phoenician texts, Anat and Astarte appear together. Thus Muller, “回štrt", TDOT, 11:426, points out that in the myth of Baal, "Astarte takes a back seat to Anat, Baal's 'sister". 
tility of animals, crops and humans. ${ }^{24}$ This worldview would make perfect sense, given the almost exclusive reliance of Canaanite agriculture on the seasons of the year. ${ }^{25}$ Keel and Uehlinger have analyzed a large number of terra-cotta figurines and other objects that indicate an obvious link between divinity and sexuality in the worldview of Canaan. ${ }^{26}$

Evidently, a corollary of this concept has been the practice of "sacred prostitution". As scholars have shown, at the height of the New Year, the ancient Sumerians celebrated the rite of the Sacred Marriage ${ }^{27}$ In this ritual, the king would join a procession to the temple of the goddess Inanna and there he engaged in a sexual relationship with the priestess of the temple, who symbolized Inanna. The sexual union was seen as an enactment of the primordial union between Dumuzi, a Sumerian shepherd god, and Innana, the goddess of sexual love, procreation and fertility. ${ }^{28}$ The sexual reenactment assured that "the forces of agricultural renewal were set in motion by sexual union". ${ }^{29}$ Most scholars agree that the Sumerian cult involved sexual relationships between men and the "sacred prostitutes" who served in the

Thus de Moor, "Batal", TDOT, 2:188ff., for the notion that one of the symbols of Batal was the "bull", He is described as engaging in sexual intercourse with a cow, symbolizing his power as a "fertility-god".

25 The changing of seasons, with its effect on vegetation, was a critical phenomenon in the life of ancient Oriental societies, where agriculture was the basic source of subsistence. Thus the relevance of the myth of Batal's disappearance in the underworld and his return in the autumn, by which he caused vegetation to die and then return to life with him; thus "Batal", ed. by Karel van der Toorn, The Dictionary of Demons and Deities in the Bible (Leiden: Brill, 1995), 132ff.

26 Keel and Uehlinger, Gods, Goddesses and Images of God in Ancient Israel (Minneapolis, MN: Fortress Press, 1998), 27-28, 54, 66-67. The authors discuss the image of the goddess "with branches of vegetation sprouting from her genitalia and the image on an Old Syrian cylinder, depicting the encounter between the "weather god and the goddess, who demonstrates her readiness for engaging in love-making by pushing her clothes aside". For the representation of the "erotic" goddesses in Sumerian and Babylonian "temple art", see also F. Pinnock, "Erotic Art in the Ancient Near East", Civilizations of the Ancient Near East, 2:2521.

27 Krammer, The Sumerians (Chicago, IL: University of Chicago, 1963), 140ff., and in general, The Sacred Marriage Rite (Bloomington, IN: Indiana University Press, 1969), esp. $67 \mathrm{ff}$.

28 See Y. Sefati, Love Songs in Sumerian Literature (Tel Aviv: Bar Ilan University Press, 1998), 208ff. For a review on scholarship and the history of the concept of Sacred Marriage see Johanna Stuckey, "Innana and the "Sacred Marriage" http://www.matrifocus.com/IMB05/spotlight.htm, and http://www.matrifocus.com/SAM05/spotlight.htm Frymer-Kensky, In the Wake of the Goddesses (New York, NY: The Free Press, 1992), $50 \mathrm{ff}$. 
temples. Naturally, the pagan worshiper expected that acts of cultic prostitution would impact the fertility of the land.

Furthermore, a number of scholars have argued that passages such as Deuteronomy 23:18; 2 Kings 23:7; 14:24; and Hosea 4:14 demonstrate that the Sumerian practice of "cultic prostitution" was introduced to the Ugaritic and Canaanite cult which in turn, influenced the practices of ancient Israel. These issues present only a secondary interest and will not be developed in our current analysis. Nevertheless, we have shown that Batal worship evidently involved a sexual element. We have also argued that Ba?alism influenced the belief system of ancient Israel. In this context, and because of passages like these, we must ask whether or not "cultic sexuality" had an impact on the religion of Israel?

Contemporary scholarship has usually taken two major positions on this issue. On the one hand, a number of scholars have argued that in biblical Israel there existed temples or other sacred places where people would practice "cultic prostitution" (e.g. Hosea 4:14). This would represent the traditional interpretation. It takes the claims of the texts at their face value. ${ }^{30}$ On the other hand, the second group of scholars have reevaluated the biblical passages and argued that, in the Bible all references to "cultic prostitution" ought to be interpreted metaphorically. ${ }^{31}$ According to Miller, the passage in case may be a way of referring to a connection with "worship practices that were regarded as idolatrous and apostate, the condemnation of which is often put in sexual terms, as for example, in Jeremiah". ${ }^{32}$ In other words, the biblical authors borrowed terms describing sexual acts (physical

Thus Brooks, "Fertility Cult Functionaries in the Old Testament", Journal of Biblical Literature 60 (1941): 227-253; S. Erlandsson, “znh", TDOT, 4:99-104; Andersen and Freedman, Hosea, Anchor Bible (New York, NY: Doubleday, 1980), 369-70; Jung, "Ba国al", ISBE, 1:377-79; Stuart, Hoseah-Jonah, WBC (Waco, TX: Word Publishing, 1987), 83-84; Stuckey, "Ancient Mother Goddesses and Fertility Cults", Journal of the Association for Research in Mothering 7.1 (2005): $38 \mathrm{ff}$.

31 Thus J. Tigay, Deuteronomy, JPS Torah Commentary (Philadelphia: Jewish Publication Society, 1996), 481; Frymer-Kensky, In the Wake of the Goddesses, 50ff.; Barstad, The Religious Polemic of Amos (Leiden: Brill, 1984), esp. 26ff.; Marsman, Women in Ugarit and Israel. Their Social and Religious Position in the Context of the Ancient Near East, Oudtestamentische Studiën vol. 49 (Leiden: Brill, 2003), 497; Wyatt, “Astarte”, Dictionary of Deities and Demons in the Bible, 113 ;

32 Miller, The Religion of Israel, 206. Miller shows that the notion of "playing the whore" was a metaphor for "idolatry". Thus Jeremiah 3:6: "Have you seen what she did, that faithless one, Israel, how she went up on every high hill and under every green tree, and there played the whore?"

PERICHORESIS 10.1 (2012) 
prostitution) and employed them metaphorically, to describe religious acts (idolatry or spiritual prostitution).

Another variation of this second view agrees with the possibility that some Israelites did engage in sexual relations with temple "prostitutes", but not under the assumption that their acts would somehow ensure the "fertility" of the land. As a number of scholars have shown, the ancient Near Eastern cultures contemporary with biblical Israel allowed for the practice of prostitution, but not in the way the Sumerians understood it. Often times, women associated with the temples of Anat or Astarte and Ba?al would offer their services to men and return a part of their earnings to the temples. They simply used the sexual prowess and appeal of the goddesses of a particular temple to attract customers. In this context, the biblical passage describe actual practices, but never with the meaning that the Sumerians applied to the "sacred marriage".

We may add here a third, mediating position, that allows for the possibility that some people engaged in "cultic sexuality", but that these represented fringe elements in the religious landscape of Israel. According to Bird, "the isolated biblical references to qedešo $\square$ represent a perverted remnant of an earlier Israelite or Canaanite cult, perpetuated in a perverted Israelite cult" ${ }^{33}$ In essence, one will never know what exactly such biblical passages did describe. ${ }^{34}$ Now, as Christiansen explained, the reassessment of the theory of cultic prostitution in Israel may be one "of the products of the feminist movement of recent years". ${ }^{35}$ We believe Christiansen is not far from the truth. Does it make sense that the Bible would have described these events in such clear terms, if the terminology (for "prostitution") had no significance whatsoever for the biblical worshiper? The "metaphorical" interpretation would work only under the assumption that the biblical authors had to revert to a metaphor in order to describe a practice that was unintelligible to their contemporaries. Yet, the passages that employ metaphorically words like $z n h$ ("prostitute, adulterous" in a "religious" setting) and qdšh ("cultic prostitute") are so numerous that they force the modern reader to ask: why would the Bible use these metaphors so often and with D. Peggy, Gender and Difference in Ancient Israel (Minneapolis, MN: Fortress Press, 1989), 75-94. 206.

Deuteronomy 21:10-34:12, 549-551. 
such a pathos, if they had no correspondent in the realm of everyday life? Why would the Bible employ a metaphor from an unknown practice in order to address such a critical issue as idolatry?

\section{The Name Ba?al in Phoenican Inscriptions}

We will now focus on the employment of the word Batal in two types of Phoenician inscriptions. The first are inscriptions that describe individuals whose names include the "theophoric" element Ba?al. The second group

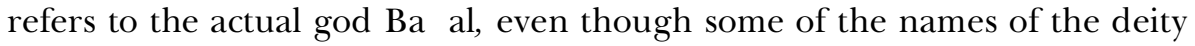
are compound names.

The name of the god $\mathrm{Ba}$ al

The name appears in several inscriptions dating from the early 10th century to the 8th century. Although most of them have been discovered in what we considered Phoenician territory, one of them (the Karatepe Inscription) belongs to the modern region of Adana, Turkey. Even though geographically Karatepe would fall outside the boundaries of Phoenicia, the fact that it lies in the vicinity to the Northern borders of Phoenicia, and that the inscription was written in the Phoenician dialect, makes it a relevant document to study.

\section{The Yehimilk Inscription}

The Yehimilk inscription (cca. 950 BC) was written on a stone probably used in connection with a sacred building. ${ }^{36}$ The text reads:

The house which Yehimilk, king of Byblos, built

He brought to life all the ruins of the houses

May Ba?al-shamem and Ba?alath-Gebal

and the assembly of the gods of Byblos, the holy ones,

prolong the days of Yehimilk and his years

over Byblos as a right king and a true

king before the holy gods of Byblos ${ }^{37}$ 
Our analysis focuses on the identity of the two deities mentioned in the inscription: Ba Zal Shamem (Ba?al of heavens) and Ba Zalath Gebal. Concerning the identity of the first god, Oden argued that both from a linguistic and a "history of religion" comparative approach, Ba?al Shamem was in fact El, the god traditionally worshipped as the chief deity in the Canaanite lists. ${ }^{38}$ Regarding the interpretation of these "compound names", a number of scholars have argued that, since the word Ba lal may mean "lord", expressions such as "Ba?al of X" could also mean "Lord of X" ${ }^{39}$ In this sense, the form $\mathrm{Ba}$ ?al would function rather as an epithet, especially when paired in the same word with a noun or a proper name. ${ }^{40}$

From a different perspective, one may also argue that "compounding" the name Ba?al with other names or nouns, should not necessarily lead to the conclusion that the original authors had other gods than Ba?al in mind. Thus, a second possibility would be that Batal Shamen was another name for Ba?al, who by this time achieved the status of the chief god. ${ }^{41}$ As we mentioned in the beginning, the employment of theophoric elements in "Canaanite and Aramaic Inscriptions", 653, Green, I Undertook Great Works, 91, and partly, Oden, "Ba国al Šamen and 国l”, The Catholic Biblical Quarterly 39 (1977): 459.

"Ba团al Šamen and ĐEl”. See also Gibson, Textbook of Syrian Semitic Inscriptions, 3:15ff., who shows that this name, placed at the beginning of the list, may indicate that the author had El in mind; similarly Albright, Yahweh and the Gods of Canaan (Winona Lake, IN: Eisenbrauns, 1968), 229. Though Gibson does not qualify this explanation, it is possible to think of El here, if we translate the word Batal with "lord" or "master", a status that was primarily attributed to El. For this translation see Keel, Gods, Goddesses, and Images of God, 280. Regardless of whether Yehimilk had Batal or El in mind, the fact that Ba?al Shamen comes first on the list attests to his preeminence, both here in other inscriptions; see Oden, "Ba国al Šamen and ĐEl”, 462-63.

39 Thus Mulder, "Ba国al", TDOT, 2:184, although Mulder does not accept this theory with the implications that others have drawn from it. Oden, "Ba团al Šamen and lEl", 457ff., offers a good analysis of the historical development of the name Batal in Phoenician sources. Oden assumes that Batal Shamen was in fact El, noting, however, that his analysis may be revised if subsequent discoveries will prove otherwise. However, Mulder, "Ba国al", TDOT, 2:193, shows that "the OT does not reveal whether another unknown divine name lies behind the name 'Balal', e.g., Hadad”. For raising the same issue, yet without arriving at a definite conclusion, see Tigay, You Shall Have No Other Gods, 11-12 (note 31).

40 Thus Mulder, "Ba国al”, TDOT, 2:185. Mulder simply presents both alternatives, showing that interpreting the evidence exclusively one way or another cannot be decisive. For example, "Josephus (C.Ap., 1.18 [118]) speaks of a temple of Zeus (=Baal) and of a temple of Heracles (=Melkart) at Tyre".

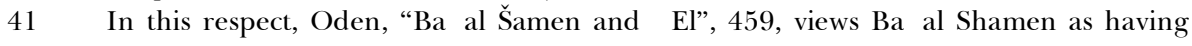
preeminence over the entire pantheon.

PERICHORESIS 10.1 (2012) 
personal names was common in Canaan and Israel. The word shamen (heavens) may also point to the link between $\mathrm{Ba}$ ?al and the storms and rain that originate in heavens and which were considered the most important natural elements in the life of the people. ${ }^{42}$ That bringing "fertility" was the natural expectation from $\mathrm{Ba}$ ?al was accepted by most of his worshippers. In this sense, the king would have dedicated the temple with the purpose of strengthening his royal position (with the help of the chief god) and securing the fertility on which life so much depended. ${ }^{43}$ Coming from the lips of a king, placing Ba?al the first on the list would not have been lost on the worshipers attending the ceremony of dedication, or on countless men and women who would have the read the inscription. ${ }^{44}$ The king was under the protection of the chief of the gods in Phoenicia. ${ }^{45}$

The identity of Batal Shamen may also depend on how one translates the phrase "Batalath gbl". Rosenthal went against the consensus and rendered Batalath as "Lord". ${ }^{46}$ This assumes that the phrase "Ba?al Shamen and Batalath of Byblos" refers to the same person: Ba?al of heavens and [also] Lord of Byblos. That is, Ba?al as a universal god and also protector of Byblos. On the other hand, as Albright argued, the context of the text suggests that here we deal with a male god (Ba?al Shamen) and his consort

42 Rollig, "Ba?al Shamen”, Dictionary of Deities and Demons in the Bible, 284.

43 Note also der Toorn, "Theology, Priests, and Worship in Canaan and Ancient Israel", Civilizations of the Ancient Near East, 2:2049, and Herrmann, "Ba'al", Dictionary of Deities and Demons in the Bible, 132-34, for the importance of Phoenician kings being endorsed by the gods.

44 Thus Rollig, "Ba国al Šamen”, Dictionary of Deities and Demons in the Bible, 149, for the significance of the fact that Balal "heads a sequence of gods, being named before El, Creator of the Earth.

45 In Oden's words, "Ba国al Šamen and ĐEl”, 463, "the leader of the pantheon and the guarantor of the rights of kings". Note also Green, I Undertook Great Works, 94, for the view that Yehimilk expected the gods to bestow long life on him in virtue of the king's own merit in creating "order and life through agricultural and construction projects". 
(Ba?alath) ${ }^{47}$ Accordingly, other scholars translated "Ba?alath" as "lady" or "mistress", thus suggesting a "consort" to Ba?al. ${ }^{48}$

Keel believes that the figure may be identified with Astarte, even though the inscription does not mention her name here. ${ }^{49}$ As we already noted, the name Astarte was mentioned in other Phoenician inscriptions, and recalled by Josephus as well. ${ }^{50}$ Even though the text makes no specific mention of the relationship between the god and his consort, we can assume from the wider background of Canaanite sources a sexual relationship as well. In this context Ba?alath corresponds to "the earth mother who symbolizes fertility" and thus partly responsible-along with $\mathrm{Ba}$ alal-for the rebirth of vegetation. ${ }^{51}$ The inclusion of two of the most important deities from Phoenicia reflects both the nature of polytheism and the depth of human pragmatism, which in this case denotes an implicit tendency for manipulation. ${ }^{52}$

"Phoenician Inscriptions", 157. Albright justifies this rendering by showing that the expression "Ba国al Gebal" was not known as a deity, while "Ba团alath-Gebal" appears repeatedly in these texts. One may also note that letter $\underline{\mathrm{t}}$ from ba Ealat appears damaged, which makes any translation open to questioning. For the feminine ending in Phoenician nouns see Harris, A Grammar of the Phoenician Language, 59, a detail which seems to support Albright's translation.

48 Liverani, "Phoenicia”, ISBE, 3:861. Likewise Oden, "Ba?al Šamen and [El,459, observes that if the original author intended the words $b$ [ $l t \mathrm{gbl}$, "we have a possible reference to Ba?al Shamem's consort, whose identity may help solve the problem of Ba?al Shamem's identity". Note Oden's referencing of Josephus, who reports that "Hiram of Tyre built a temple for Zeus Olympios" (Ag. Ap. 1.113 and 1.118, and Ant. 8.145 and 8.147).

49 Keel, Gods, Goddesses, and Images of God, 339, and also Mulder, "Ba罒", TDOT, 2:189 and Holladay, Jeremiah 1, Hermeneia (Philadelphia, PA: Fortress Press, 1986), 254ff., who points to the Babylonian-Assyrian name Ishtar. Accordingly, Astarte was called "the Queen of Heavens" (malkat hašamayim) in Philistine and Phoenician coastal cities. For the veneration of the Queen of Heavens in Jerusalem see Jeremiah 7:18 and $44: 17,25$, where the Israelites brought cakes and burned incense to her. On the other hand, Mullen, Dictionary of Deities and Demons in the Bible, 264, suggests that "the inscriptional evidence from the first millennium demonstrates that she was the leading deity of the city" and that she "could have been a syncretistic deity that combined some of the aspects of Asherah, Astarte, and Anat". One may also note der Toorn, "Theology, Priests, and Worship in Canaan and Ancient Israel", 2049, for the prerogative of the Phoenician kings as priests of Astarte, and of the mother-queen, as priestess.

$50 \quad$ For evidence see Muller, “国štrt”, TDOT, 11:428; Day, “Ashtoreth”, $A B D, 1: 493$; Wyatt, "Astarte", Dictionary of Deities and Demons in the Bible, 111.

51 Thus Moscati, The World of the Phoenicians (London: Weidenfeld and Nicolson, 1968), 32.

52 Crawford, Blessings and Curse in Syro Palestinian Inscriptions of the Iron Age (New York, NY: Peter Lang, 1992), 65, observes that the "wish for long life is one of the most

PERICHORESIS $10.1(2012)$ 
One may now understand better why the sacrificial cult was understood as an essential means to secure "life, health, political prowess, reliable food supplies, and reproductive success". In fact, a number of Old Testament passages show that cultic practices that were distinctly Phoenician and Canaanite had an impact upon ancient Israel as well (Deuteronomy 23:18-19, Amos 2:7-8, and Hosea 4:13). Evidently, the figure of Batal, the bringer of rain "on which the fertility of the soil depends", marked the religious consciousness of many to such an extent that Ba?al was worshiped along with Adonai, the God of the Hebrews. In many minds, "Yahweh and Ba?al differed but little". ${ }^{3}$

In this context, one may remember that bloody conflict Elijah spearheaded against the worshipers of Ba?al took place at Mount Carmel, "the borderland between Israel and Phoenicia". ${ }^{54}$ Even though Ahab built a temple to Batal in Samaria in the 9th century (1 Kings 16:32), very likely his initiative fit comfortably within the religious worldview that had formed previously in Northern Israel. When Elijah accused the Israelites of "limping on two crutches" (1 Kings 18:21), they said nothing. The closer Israel dealt to Phoenicia, the stronger the urge for northerners to blend Yahwistic and Ba?alistic worship. That is why Elijah attempted to replace "the royal programme 'Yahweh and Baal' with the slogan 'Yahweh or Baal'.,"55

common greetings/blessings" in the Syro-Palestinian inscriptions. A similar tendency can be observed in the Old Testament as well, where both kings and people are promised "longer life if they keep Yahweh's ways" (Deuteronomy 5:33; Psalm 91:6). However, we believe that the Old Testament worldview differs from this attitude of polytheistic pragmatism, where one calls on and, through ritual manipulates, as many gods as possible in order to secure benefits such as these.

53 Thus Bright, "Hebrew Religion", Interpreters Dictionary of the Bible (Nashville, TN: Abingdon Press, 1962), 2:565. For this phenomenon see also McKenzie, "God and Nature in the Old Testament", The Catholic Biblical Quarterly 14 (1952): 129ff.; Scharlemann, "God is One", The Lutheran Quarterly 9.3 (1959): 235; Arnold, "Religion in Ancient Israel”, ed. by D. W. Baker, The Face of Old Testament Studies (Grand Rapids, MI: Baker,

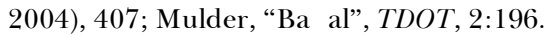

54 Thus Albertz, The History of Israelite Religion, vol. 1 (London: SCM Press, 1994), 153. Albertz, citing Alt, agrees that the Ba?al cult rose to preeminence during the reigns of Omri and Ahab, but that the tendency for syncretism had been there all along. David built an altar to YHWH when he incorporated the region into his kingdom, altar which "Elijah had later found destroyed" (1 Kings 18:30). After the decision of Solomon to reward king Hiram with twenty cities in the land of Galilee (1 Kings 9:11), the YHWH cult may have been displaced by the Batal cult. At any rate, by the time of Elijah, many of the typical northern Israelites would have felt no remorse to call on Ba国al.

55 Rainertz, A History of Israelite Religion, 154.

PERICHORESIS 10.1 (2012) 


\section{The Kilamuwa Inscription}

Another text that contains the name Balal, compounded by a second name, comes from the Kilamuwa inscription (Zenjirli, cca. 830 BC) ${ }^{56}$ The historical context underlying the content of the inscription points to the dedication of the palace where it was found. ${ }^{57}$ The name of Batal appears in the following phrase:

And if anyone smashes this inscription, may Ba国alšemed who belongs to Gabbar smash his head, and may Ba⿴囗大) ammon who belongs to BMH and Rakkabel, lord of the dynasty, smash his head.

Although the occasion that prompted the writing could have been a celebratory event, the literary context in which the name Balal appears includes a "curse-like" formula, a fact which connects this with typical "sarcophagus" inscriptions. According to Gibson, the name Ba?al Šemed refers to a "title of Hadad (Baal), the chief god of the Arameans of Zenjirli... meaning 'lord of the mace'." ${ }^{58}$ The Ugaritic root smd points to a "weapon used by Ba?al in his victory over the ocean god Yam" ${ }^{59}$ One may conjecture, then, that the term šmed may have been more a "function" or "role" marker, than an identity description. It might have connoted the role of Ba?al as a warrior, a function not uncommon to Phoenician deities and one obviously convenient to a king with military obligations. ${ }^{60}$

Concerning the identity of Baal Hammon, one may set the name against a number of references in the Old Testament of the word $h m n$. In Phoenici-

For historical/literary context, translation and analysis see Green, I Undertook Great Works, 136ff. and O'Connor, "The Rhethoric of the Kilamuwa Inscription”, Bulletin of the American Schools of Oriental Research 226 (1977): 15-30.

57 Thus Gibson, Textbook of Syrian Semitic Inscriptions, $30 \mathrm{ff}$.

$58 \quad$ Ibid., Gibson. The Old Testament does not use the word $\check{s} d d$ with this sense, but it employs the verb šadad in numerous texts, with the meaning of "destroy", "devastate" and "despoil”. Thus “šdd", HALOT; " $\check{s} d d "$, ed. by R. L. Harris Theological Wordbook of the Old Testament (Chicago, IL: Moody Press, 1981, BibleWorks Electronic Edition).

59 See Pritchard, ANET, 130, and Bunnens, A New Luwian Stele and the Cult of the Stormgod at Til Barsib-Masuwari (Leuven: Peeters, 2006), 79ff., for the conflict between Yam and Ba?al. Baal used the clubs/mace built by the artisan Kutharu-wa-Hasisu (Kothar) in order to defeat Yam.

60 Similarly Bunnens, A New Luwian Stele, 79, who shows that the "Mace-God' and the 'Lord of the Mace'... may be one and the same aspect of the Storm-God", even though Bunnen's argument is more complex and includes references to other inscriptions as well. 
an, the root $h m n$ occurs at times with the sense of "pillar" or "incensealtar" ${ }^{61}$ The Old Testament makes numerous references to the idolatrous altars for which the people would be punished by God. ${ }^{62}$ Granted, the data does not clarify the precise identity of Ba?al Hammon, but it allows for his (albeit indirect) influence in ancient Israel. ${ }^{63}$

The expression Batal Hammon has also been translated by some as "lord of [Mount] Amanus, [this suggestion] placing the god in the area of Zenjirli" ${ }^{64}$ The region was in the proximity of a mountain range in northern Ugarit, which included Amanus. ${ }^{65}$ As a mountain god, Ba?al Hammon controlled the fertility of the region. In this sense, he was often paired with the goddess Tanit who, in turn, shared similar characteristics with Astarte. Note also that Markoe lists evidence from late 7th and 6th century of possible "child sacrifices" brought in honor of Ba?al Hammon. The so called molk sacrifices "may have been connected with the fertility sacrifices celebrated in March" ${ }^{66}$ This analysis is conjectural, but if (only approximately) correct, it would place the strong condemnation by the Old Testament in a more appropriate context. We may at least conclude that, if one takes into account the references that Kilamuwa made to flocks, oxen, and herds, the picture of Ba?al Hammon as a god of fertility becomes clearer ${ }^{67}$ Again, as with Yehimilk, Kilamuwa's vision of the gods was individualistic, exclusively pragmatic and inclined to manipulation. The boasting of the king implied that he was as important as the gods. Yet, for all his arrogance, the king feared that thieves or rivals may desecrate the funerary monument. That is

Harris, A Grammar of the Phoenician Language, 102; Gibson, Textbook of Syrian Semitic Inscriptions, 39, and Zevit, Religions of Israel, 340, who argues that the hamma "refers to model shrines of various sizes made of wood and clay".

62 Leviticus 26:30; Ezechiel 6:4, 6; Isaiah 27:9; cf. 2 Chronicles 27:4.

63 Thus "hmn", HALOT, for the sense of "sun pillar used in idolatrous worship" and the name Ba Zalhmn as epithet of solar Batal in Phoenician texts.

64 Gibson, Textbook of Syrian Semitic Inscriptions, 39. Moscati, The World of the Phoenicians, 138 , translates this term as "lord of the perfume altar", pointing to the "widespread practice of offering incense, indicated by the stelae where this altar frequently appears".

65 Thus Markoe, The Phoenicians, vol. 2, Peoples of the Past (Berkley, CA: University of California Press, 2000), 130ff. Note, however, the interpretation of Lipinski, Studies in Aramaic Inscriptions and Onomastics, vol. 2 (Leuven: Peeters, 1994), 206ff., who argues that it was the mount Amanus which was originally deified; hence, the veneration of the god Hamon.

66 Markoe, Ibid., 134ff.

67 See O'Connor, "The Rhethoric of Kilamuwa”, 19 (lines 26-28 of the inscription).

PERICHORESIS $10.1(2012)$ 
why he called on the gods with a do ut des mentality and obliged them to intervene against the perpetrators. ${ }^{68}$

\section{The Karatepe Inscription of Azitiwadda}

The Karatepe inscription was discovered in what is today the province of Adana, modern Turkey. It belonged to the portal orthostats at Karatepe, the fortress of the king Azitiwadda (740-710 BC) ${ }^{69}$ The historical context that can be recovered from the text implies that Azitiwadda lived during and after the reign of king Awarku. It is possible that Azitiwadda may have been either "a high official of Awarku's court or a prince of royal blood..., and that after Awarku's death he acted as a regent while his son was still a minor". ${ }^{70}$ The inscription contains a bilingual "Luwian (Hittite)-Phoenician" text about the achievements of Azitawadda. In it, Azitawadda refers to several deities:

I am Azitawadda, the blessed of Ba国, the servant of Ba?

Ba回l made me a father and a mother to the Dannunites

I have added horse to horse, shield to shield, and army to army, by virtue of $\mathrm{Ba}$ 国 and the Gods (El)

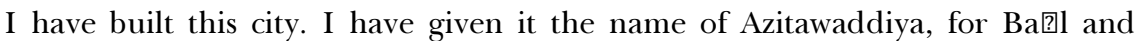

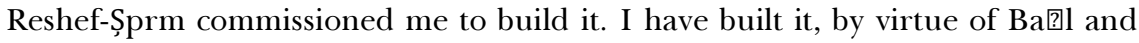
by virtue of Reshef-Șprm...I have established Ba@l-Krntryš.

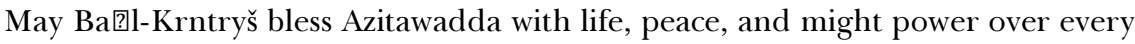

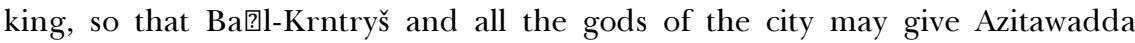
length of days...If there be a king among kings... who shall wipe out the name of Azitawadda from this gate and put down his name...let Ballshamen and El-thecreator-of-the-earth and the Eternal-Sun and the whole Group of the Children of the Gods wipe out that ruler...

Thus Herrmann, "Ba'al" Dictionary of Deities and Demons in the Bible", 134, for the notion that Ba'al "is mentioned besides other gods as guarantor of the inviolability of the inscription". For the significance of formulas of "curse", Scharbert, "rr", TDOT, 1:416ff., shows the curse to be "a forceful word producing destructive powers". Often times the curse meant "the only or last legal method of effectively discouraging violators of the law and evildoers".

69 K. Lawson Younger, "The Phoenician Inscription of Azitiwadda", Journal of Semitic Studies 43.1 (Spring, 1988): 11; Rosenthal, "Canaanite and Oriental Inscriptions", 653654 ;

70 Textbook, 43. Rosenthal, "Canaanite and Aramaic Inscriptions", 653, believes that Azitiwadda was in fact the son of king Awarku. Azitiwadda ruled between 730-710 BC.

PERICHORESIS 10.1 (2012) 
The deities that Azitawadda mentions in the list are Ba?l, Ba?l-Krntryš, the Gods, Reshef-Sprm and Ba?lshamen. Since the focus of this study is the god $\mathrm{Ba}$ ?al, having already analyzed the meaning of the names Ba?l and Ba?lŠamen, we will concentrate for the reminder of the analysis on the identity of Ba?l-Krntryš. ${ }^{71}$ According to Gibson, the word KRNTRYŠ is non-Semitic, and points rather to a geographical place. Hence it is possible that this "deity was a form of the Anatolian Weather-God". ${ }^{72}$ Accordingly, Azitawadda

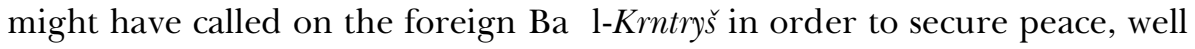
being, and for protecting his inscription from being defaced. Oden argues that not only the name, but apparently the cult of this area, seems unusual. ${ }^{73}$ Another interpretation takes the listing "in order" of the deities and assumes that, since "double or triple designations of a single deity are not uncommon", it is conceivable that the names may actually serve as "appellations of the god El" ${ }^{74}$ However, this interpretation does not seem to take into account the fact that the name $\mathrm{El}$ appears along with Ba?l-Krntryš. De Moor suggested that in certain contexts, the name Ba?al was not used in an absolute sense. When connected to a second element, the name may simply mean "Lord of..." and serve as an "appellative honorific title of another god". ${ }^{75}$ De Moor suggests a second possibility, namely, that "b?l followed by a genitive frequently means the storm-god Baal". ${ }^{76}$ In other words, the genitive form that followed the name Ba?al could in fact nominate the "local manifestation" of the great god Ba?al (e.g., Ba?al, that is, Krntryš). Ultimately, the fact that the inscription lists several combinations of the Ba?al name, points to "no small degree of religious syncretism... at Karatepe". ${ }^{77}$

We may clarify the picture of Ba?l-Krntryš by also analyzing the role that the god played (in the worldview of this inscription). Azitawadda "established" Ba?l-Krntryš at Karatepe, he calls on Ba?l-Krntryš to bless him with "life, peace, and mighty power", with "length of days, a great number of

71 Since in this paper we focus on the god Batal we will not attempt a full analysis on the name Reshef-Sprm either.

72 Textbook of Syrian-Semitic Inscriptions, 43, 60.

73 “Ba国al Šamen and QEl”, 461. Oden cites Donner and Rollig's characterization of the name Krntryš, as "wohl kleinasiathisch" (see, KAI 2.42).

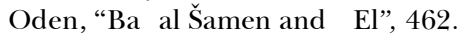

"Ba?al", TDOT, 2:184-85,

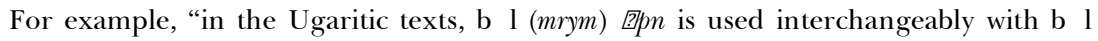
(m) and hd (Haddu) quite regularly".

77 Thus Oden, "Ba@al Šamen and ĐEl”, 462, quoting O'Callaghan, “An Approach to Some Religious Problems at Karatepe”, ArOr 18 (1950): 354-65. O'Callaghan believes that in Karatepe one finds Anatolian, Egyptian and Syro-Mesopotamian influences".

PERICHORESIS 10.1 (2012) 
years, good authority", and finally to bestow upon Azitawadda's people "plenty to eat and wine (to drink)", "oxen, small cattle", and "many children". Evidently, among these blessings, the abundance of crops and the animal and human offspring point to Ba?l-Krntryš as a god of rain and fertility. ${ }^{78}$ Finally, since Batal and Reshph-SRPN commissioned Azitawadda to build the city (and the temple), it is plausible that they "were part of the decision-making counsel of the gods, who were involved in building the Temples". ${ }^{79}$

The Name Ba Zal in Compounded Names

The following analysis will focus on several inscriptions that have been dated to a time frame between 1000-700 BC. The criterion for selection is the name of the god Ba?al. The inscriptions are valuable because they offer direct evidence of the understanding and practice of the cult of Ba?al in Phoenicia.

The Ahiram Inscription (cca. $950 \mathrm{BC}$ )

As the examples included bellow will show, the majority of Phoenician kings of the 10th-9th centuries had theophoric names. One of the better known inscriptions which contain a theophoric name is the Ahiram inscription. The name appears on a "sarcophagus" that 'Ittoba'l, the king of Byblos, made for his father Ahiram. A number of scholars have made the association between 'Ittoba'l and Ethbaal from 1 Kings 16:31, the father of Jezebel, and the king of the Sidonians. In fact, Josephus, quoting Menander, identified Ethbaal as "the priest of Astarte" and fellow sufferer with Ahab from the draught described in 1 Kings $17 .^{80}$ The inscription is fragmentary, but the sentence that concerns us states: "the coffin which [It]obaal, son of Ahiram, king of Byblos, made for his father..." ${ }^{81}$ The expression contains the key word 'ittoba'l.

78 Thus de Moor, TDOT, 2:186.

79 Thus Hurowitz, I Have Built You an Exalted House.Ttemple Building in the Bible in the Light of Mesopotamian and North-West Semitic Writings, vol. 5 JSOT/ASOR (New York, NY: Continuum International, 1992), 140.

80 See Viviano, "Ethbaal", $A B D, 2: 645$ and the references to Josephus Ant. viii: 13, 12; Ap. i:18. For the debate on dating and questions of historical context see Albright, W.F. "Phoenician Inscriptions of the Tenth Century BC from Byblos", JAOS. LXVII (1947): 153-160; Vriezen, Palestinian Inscriptions (Leiden: Brill, 1951), 7; Gibson, Textbook of Syrian Semitic Inscriptions, 3 vols. (Oxford: Clarendon, 1982), 3:15ff.; Bernal, Cadmean Letters (Winona Lake, IN: Eisenbrauns, 1990), 15ff.; Mykytiuc, Identifying Biblical Persons in Northwest Semitic Inscriptions 1200-539 B.c.e. (Society of Biblical Literature, 2004), 238. 
This is a classic example of a theophoric name, containing the name of $\mathrm{Ba}$ ?al in the second part. In our context, 'ittoba'l may be translated as "with him Batal". Gibson suggests that the position of the $3 \mathrm{~ms}$ pronominal suffix (here not "w" but "h", situated between the proper name and the proposition "⿴囗十", "with") led to the formation of a diphthong with the preceding vowel; hence its reduction. ${ }^{82}$ It is very likely that the name "Batal with him" might have served as a means to strengthen Ethbaal's royal position. The king was appointed by, and under the protection of, the god Ba?al. ${ }^{83}$

\section{The Abiba国al, Eliba团al, and Shipitba国al Inscriptions.}

Another set of example of names which contain the theophoric element "baal" are those of Abiba?al, Eliba?al, and Shipitba?al. We will also study the role that the god Ba?al played in the lives of these kings later, but for our immediate purpose, it is important to examine the meaning of their names. The inscriptions contain the names in the following contexts:

The statue which Abibaal ( ॠviba Đal) king of Byblos, son of Yehimilk...

king of Byblos, brought from Egypt for Ba?al[ath Gebal, his lady.

May Ba?alath Gebal prolong the days of Abibaal and his years] over Byblos! $!^{84}$

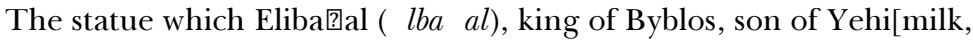
king of Byblos,] made [for Ba]alath-Gebal, his lady. May Ba?alath[-Gebal] prolong [the days of E]libaal and his years over [Byblos]! $!^{85}$

The wall which Shipit-Ba?al (šipi.tba Zal), king of Byblos, son of Elibaal, king of Byblos, son of Yehimilk, king of Byblos, built for Ba?alath (New Haven, CN: American Oriental Society, 1936), 83-84, for the combination between the preposition $2 \mathrm{t}$ with the $3 \mathrm{~ms}$ pronominal suffix and the name Ba?al. Heroes', " an indication that he could be the protector of the king in the battles that he waged against the enemies; thus, de Moor, "ba'al", TDOT, 3:188.

84 The Inscription of Abibaal (on a statue of king Shishak, cca. 925 BC). See Albright, "Phoenician Inscriptions", 157.

85 The Inscription of Elibaal (on a statue of Osorkon I, cca. 915 BC). See Albright, "Phoenician Inscriptions", 158.

PERICHORESIS 10.1 (2012) 
Gebal, his lady. May Ba?alath-Gebal prolong

the days of Shipit-Ba?al and his years over Byblos!"

All three texts are part of dedicatory inscriptions, in which the king claims his merit for having built or restored the "houses" of the gods (or the goddesses). In the case of the first name, one will note the proper name $\mathrm{Ba}$ ॠal attached to the prefix $\square$ by, that is, "[my] father". As Harris argued, there is no indication that case endings "were still expressed" in all early Phoenician dialects. ${ }^{87}$ That is why a Phoenician speaker could have pronounced the form 5 by (avi), that is, with first-common-singular suffix. This was possible because in "many Phoenician forms " $y$ " was absorbed into a preceding vowel in the same syllable". ${ }^{88}$ This also means that name may well have had the meaning "my father" ([by) [is] Ba [al (Master/Lord), or "of my father, Ba Zal" (Abibalos, in Josephus, Ant. 8.5). ${ }^{89}$

The second name contains the forms ba Đal Zel. If Harris is correct, and if a first-common-singular suffix need not have been written in order to be read, then one could have read the expression as elyba lal. In a word-forword translation, the name would mean "my god" (Zlely) [is] ba Zal, or "my god, the Lord". ${ }^{90}$ Without forcing the limits of the analogy, we may point to the Hebrew name of Elijah (Belyyiahu). This name too was formed of the same two concepts: the names of God $(E l)$ and Lord $(Y H W H)$ which, in translation meant "my God" (最ly) "is Lord" (yiahu). ${ }^{91}$

Finally, the third name read sip tba Đal. In Phoenician, as in other Northwestern Semitic dialects, the root $\breve{s} f . t$ could mean "[to] judge, govern" (as verb) and "governor, law giver" (as noun). ${ }^{92}$ The full name might have

86 Inscription of Shipit-Ba Zal (end of tenth century BC).

87 A Grammar of the Phoenician Language (New Haven, CT: American Oriental Society, 1936), 61, 73 .

88 Ibid., 30-31, 75. For example, 2 Samuel 5:11 mentions the name of the king Hiram, and 1 Kings 5:24 (Hirom), the same name which appears in early Phoenician as hrm or hi-ru-um-mu. Note also Albright, "Phoenician Inscriptions", 158, for rendering Zuiba Zal as Abibaal.

89 For the association of Batal names with the royal descendants in Phoenicia see also Markoe, The Phoenicians, 88.

90 In Phoenician and Hebrew, El meant "god" or "God;" thus Harris, Ibid., 77. Using this analogy, we may point to the Hebrew name of Elijah (Belyyiahu), which meant "my God" (Bely) "is Lord" (yiahu).

91 Thus "Belyyiahu”, HALOT; TWOT.

92 Harris, A Grammar of the Phoenician Language, 153. For the meaning of $̌ f . t$ in Amorite, Akkadian, Ugaritic, and Punic (Phoenician) dialects see "šft", HALOT.

PERICHORESIS 10.1 (2012) 
had the meaning of "He judged [with the help] of Ba?al", or " $B a$ ॠal judged". In other words Šipitba Zal claimed that $B a$ Zal invested him with the authority to govern and judge the people. Alternatively, though less certainly, it could mean that when Sipitba Zal judges and/or governs, it is in fact $B a$ Zal that judges and/or governs through him. In other words, Sipitba Zal is the human representative of the god. ${ }^{93}$

\section{Conclusions}

We have stated already that Ba?al was a deity of fundamental significance in the Ancient Near East, and particularly in biblical Israel. First, the importance of the god has been attested by the frequency with which it was used in Ugaritic and Canaanite mythology. Second, we know that the image of Ba?al, as a "weather god" and "war god" appears in many inscriptions, artifacts and statuettes from Israel, Phoenicia and Syria ${ }^{94}$ We also know that $\mathrm{Ba}$ ?al temples and altars existed both outside and inside of Israel (Judges 6:25; 1 Kings 16:32).$^{95}$ The Bible affirms on two occasions that hundreds of

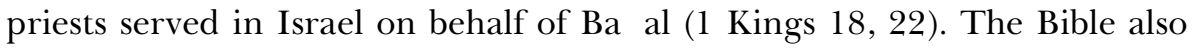
refers to $\mathrm{Ba}$ ?al by name over 66 times, although many of the references to "idols" and "gods" probably pointed to Batal as well. Several of these references link Ba国al with the phenomena of rain and fertility (e.g., 1 Kings 18; Hoseah 2). This statistic alone makes Ba国al the most important deity, besides Elohim and YHWH, in the whole of the Old Testament.

Finally, the high status of the god is confirmed "by the frequency of Batal as theophoric component in personal names" ${ }^{96}$ In other words, the name $\mathrm{Ba}$ ?al as the theophoric element in compound names is the second most used name in the Old Testament, after El and YHWH. ${ }^{97}$ We hope to Jeremiah 38:1; 2 Samuel 3:4 (the fifth son of David), and $\check{s}^{e} f a t^{e} y a h u$, in 1 Chronicles 12:6 (one of David's helpers from Benjamin), with the sense of "YHWH has obtained justice".

94 See Keel and Uehlinger, Gods, Goddesses and Images of God in Ancient Israel, 58, 60, 76, $244 f f$.

95 Thus Haran, Temples and Temple-service in Ancient Israel (Indiana, IN: Eisenbrauns, 1985), 51, 57; Smith, The Ugaritic Ba Zal Cycle, 61; Dever, "Palaces and Temples in Canaan and Ancient Israel", Civilizations of the Ancient Near East, 1:605-14, and "Temples and Sanctuaries: Syria-Palestine", $A B D, 6: 376-80$.

96 "Ba国al", Dictionary of Deities and Demons in the Bible, 133.

97 Note Tigay, You Shall Have No Other Gods, on the theophoric elements in the Old Testament. 
have shown that the god Ba?al played a major role in Phoenician religion as well. Both as a theophoric element and as the name of the god Ba?al, this deity occupied the religious conscience and practical life of the Canaanites like no other god ever did. The fact that Ba?al was placed first in lists of deities, and that the name of three successive Phoenician monarchs bore the theophoric element $\mathrm{Ba}$ ?al, proves the high status that he received in the eyes of the worshipers. Beginning with the 10th century BCE, Phoenicia played a major role in the relationship with Israel and its religion left an indelible mark upon the religious practices of the people of God.

\section{Bibliography}

Albright, W. F. "Phoenician Inscriptions of the Tenth Century BC from Byblos". JAOS. LXVII (1947): 153-160.

. Yahweh and the Gods of Canaan. Winona Lake, IN: Eisenbrauns, 1968.

Arnold, B. T. "Religion in Ancient Israel", The Face of Old Testament Studies. Edited by D. W. Baker. Grand Rapids, MI: Baker, 2004.

Baker, D. "God, Names of". Dictionary of the Pentateuch. Downers Grove, IL: Intervarsity Press, 2003, 359-68.

Bird, P. "To Play the Harlot: An Inquiry into an Old Testament Metaphor". Gender and Difference in Ancient Israel. Edited by D. Peggy. Minneapolis, MN: Fortress Press, 1989, 75-94.

Barstad, H. The Religious Polemic of Amos. Leiden: Brill, 1984.

Baumgarten, A. The Phoenician History of Philo of Byblos. Leiden: Brill, 1981.

$\begin{array}{llll}\text { Period } & \text { Theophoric names } & \begin{array}{l}\text { Yahwistic } \\ 0(0 \%)\end{array} & \begin{array}{l}\text { Probably pagan } \\ 3(100 \%)\end{array} \\ \text { Patriarchal } & 3 & 3(50 \%) & 3(50 \%) \\ \begin{array}{l}\text { Exodus-Conquest } \\ \text { Judges-United }\end{array} & 6 & 140(86 \%) & 23(14 \%) \\ \begin{array}{l}\text { Monarchy } \\ \begin{array}{l}\text { Divided Monarchy } \\ \text { Late Judah }\end{array}\end{array} & 127 & 123(97 \%) & 4(3 \%) \\ \begin{array}{l}\text { Uncertain, but not } \\ \text { Post exilic }\end{array} & 97 & 92(95 \%) & 5(5 \%) \\ \text { Total } & \mathbf{4 6 6} & 55(79 \%) & 15(21 \%) \\ & & \mathbf{4 1 3 ( 8 9 \% )} & \mathbf{5 3 ( 1 1 \% )}\end{array}$

Tigay argued that a certain percentage of names such as these "probably represent a meaningless residue of previous onomastic practices". See also Zevit, The Religions of Ancient Israel, 607, who concludes correctly that this evidence at least proves that "the spread of Yahwism in Israel is pre-Davidic", regardless of whether many of the adherents adopted a more syncretistic approach to faith and worship. 
Bernal, M. Cadmean Letters. Winona Lake, IN: Eisenbrauns, 1990.

Block, D. "God", Dictionary of Old Testament Historical Books. Edited by B. T. Arnold. Downers Grove, IL: Intervarsity Press, 2005, 341-55.

A. Bonnano, Archaeology and Fertility Cult in the Ancient Mediterranean. Amsterdam: John Benjamins Publishing, 1986.

Bondi, S. F. "The Origins in the East". The Phoenicians. Edited by S. Moscati. New York, NY: Abbeville Press, 1989, 23-29.

Bright, J. "Hebrew Religion". Interpreters Dictionary of the Bible. Edited by G. Buttrick. 5 volumes. Nashville, TN: Abingdon Press, 1962, 2:560-570. . A History of Israel. Third edition. Philadelphia, PA: Westminster, 1981.

Brooks, B. A. "Fertility Cult Functionaries in the Old Testament". Journal of Biblical Literature 60 (1941): 227-253.

Bunnens, G. and Hawkins, J. D. A New Luwian Stele and the Cult of the Stormgod at Til Barsib-Masuwari. Leuven: Peeters, 2006.

Crawford, T. Blessings and Curse in Syro Palestinian Inscriptions of the Iron Age. New York, NY: Peter Lang, 1992.

Day, J. "Ashtoreth". The Anchor Bible Dictionary. Eidted by N. Freedman. New York, NY: Abingdon, 1992, 1:491-94.

Day, J. "Batal". The Anchor Bible Dictionary. Edited by N. Freedman. New York, NY: Abingdon, 1992, 1: 545-49.

de Moor, M. "Ba?al". Theological Dictionary of the Old Testament. Edited by G. J. Botterweck. Grand Rapids, MI: Eerdmans, 1988, 2:181-92.

Dever, W. "Palaces and Temples in Canaan and Ancient Israel". Civilizations of the Ancient Near East. Edited by J. M. Sasson. New York, NY: Scribners, 1995, 1:605-14.

Green, D. I Undertook Great Works. The Ideology of Domestic Achievements in West Semitic Inscriptions. Tübingen: Mohr Siebeck, 2010.

Eichrodt, W. Theology of the Old Testament. Philadelphia, PA: Westminster, 1961.

Gibson, J. Textbook of Syrian Semitic Inscriptions. Three volumes. Oxford: Clarendon, 1982.

Gray, J. The Legacy of Canaan: The Ras Shamra Texts and Their Legacy to the Old Testament. Leiden: Brill Archive, 1957.

Haran, M. Temples and Temple-service in Ancient Israel. Indiana, IN: Eisenbrauns, 1985.

Harden, D. The Phoenicians. New York, NY: Frederick A. Praeger, 1962. 
Harris, Z. S. A Grammar of the Phoenician Language. New Haven, CT: American Oriental Society, 1936.

Hawthorne, G. F. "Name". ISBE. Grand Rapids, MI: Eerdmans, 1986, 3:481-483.

Hebrew and Aramaic Lexicon of the Old Testament. Editors W. Baumgartner, L. Koehler. Leiden: Brill, 1994-2000.

Herrmann, W. "Ba'al" Dictionary of Deities and Demons in the Bible. Second edition. Edited by K. van der Toor. Grand Rapids, MI: Eerdmans, 1999, 132-139.

Holladay, W. L. Jeremiah 1. Hermeneia. Philadelphia, PA: Fortress Press, 1986.

Hurowitz, V. I Have Built You an Exalted House. Temple Building in the Bible in the Light of Mesopotamian and North-West Semitic Writings. Volume 5. JSOT/ASOR. New York, NY: Continuum International, 1992.

Jung, K. G. "Ba团al”, ISBE. Grand Rapids, MI: Eerdmans, 1986, 1:377-79.

Kaufmann, Y. The Religion of Israel. Translated by M. Greenberg. New York, NY: Schoken Books, 1960.

Krammer, S. The Sumerians. Chicago, IL: University of Chicago, 1963. . The Sacred Marriage Rite. Bloomington, IN: Indiana University Press, 1969.

Lipinsky, E. Studies in Aramaic Inscriptions and Onomastics. Volume 2. Leuven: Peeters, 1994.

. "The Phoenicians". Civilizations of the Ancient Near East. Two volumes, Edited by J. M. Sasson. New York, NY: Scribner, 1995, 2:1321-1333.

Liverani, M. "Phoenicia”. ISBE. Grand Rapids, MI: Eerdmans, 1986, 3:85362.

Keel, O. and Uehlinger, C. Gods, Goddesses and Images of God in Ancient Israel. Minneapolis, MN: Fortress Press, 1998.

Lawson Younger, K. "The Phoenician Inscription of Azitiwadda". Journal of Semitic Studies 43.1 (1988): 11-47.

Markoe, G. The Phoenicians. Volume 2. Peoples of the Past. Berkley, CA: University of California Press, 2000.

Marsman, H. Women in Ugarit and Israel. their social and religious position in the context of the ancient Near East. Oudtestamentische studiën volume 49. Leiden: Brill, 2003.

McKenzie, J. L. "God and Nature in the Old Testament". The Catholic Biblical Quarterly 14 (1952): 125-145.

Miller, P. The Religion of Ancient Israel. Louisville, KY: Westminster, 2000. 
Moscati, S. The World of the Phoenicians. London: Weidenfeld and Nicolson, 1968.

Muller, H.P. “回štrt”. Theological Dictionary of the Old Testament. Edited by G. J. Botterweck. Grand Rapids, MI: Eerdmans, 1988, 11:423-34.

Mykytiuc, L. Identifying Biblical Persons in Northwest Semitic Inscriptions. Leiden: Brill, 2004.

Merrill, E. Everlasting Dominion. Nashville, TN: Broadman, 2006.

Morenz, S. Egyptian Religion. Ithaca, NY: Cornell University Press, 1992.

Noegel, S. B. "Phoenicia/Phoenicians". Dictionary of the Old Testament Historical Books. Edited by B. T. Arnold. Downers Grove, IL: Intervarsity, 2005, 792-798.

O'Callaghan, R. T. "An Approach to Some Religious Problems at Karatepe". ArOr 18 (1950): 354-65.

O'Connor, M. "The Rhethoric of the Kilamuwa Inscription". Bulletin of the American Schools of Oriental Research 226 (1977): 15-30.

Oden, R. A. "Ba团al Šamen and ĐEl”. The Catholic Biblical Quarterly 39 (1977): 458-73.

Pekham, B. "Phoenicia: History of". The Anchor Bible Dictionary. Edited by N. Freedman. New York, NY: Abingdon, 1992, 5:349-57.

Pope, M. El in the Ugaritic Texts. Leiden: Brill Archive, 1955.

Prichard, J. B. Ancient Near Eastern Texts Relating to the Old Testament. Third edition. Princeton, NJ: Princeton UP, 1969.

Ribichini, S. "Beliefs and Religious Life". The Phoenicians. Eidted by S. Moscati. New York, NY: Abbeville Press, 1989, 104-125.

Scharbert, J. "rr". Theological Dictionary of the Old Testament. Edited by G. J. Botterweck. Grand Rapids, MI: Eerdmans, 1988, 1:405-18.

Scharlemann, M. H. "God is One". The Lutheran Quarterly 11.3 (August 1959): 231-36.

Schmitz, P. C. "Phoenician Religion". The Anchor Bible Dictionary. Edited by N. Freedman. New York, NY: Doubleday, 1992, 5:357-363.

Smith, M. S. "Myth and Mythmaking in Canaan and Ancient Israel". Civilizations of the Ancient Near East. Two volumes. Eidted by J. M. Sasson. New York, NY: Scribner, 1995, 2:2031-41. . The Ugaritic Ba Zal Cycle. Leiden: Brill, 1994/2009. . The Origins of Biblical Monotheism. New York, NY: Oxford University Press, 2001. . The Early History of God. Grand Rapids, MI: Eerdmans, 2002. 
Stuart, D. "Names, Proper". ISBE. Grand Rapids, MI: Eerdmans, 1986, 3:483-88.

Stuckey, J. "Innana and the 'Sacred Marriage" (http://www.matrifocus.com/IMB05/spotlight.htm).

\section{light.htm).}

. "Sacred Prostitutes" (http://www.matrifocus.com/SAM05/spot-

. Stuckey, J. “Ancient Mother Goddesses and Fertility Cults”. Journal of the Association for Research in Mothering 7.1 (2005): 32-44.

Theological Wordbook of the Old Testament. Edited by R. L. Harris. Chicago, IL: Moody Press, 1981. BibleWorks Electronic Edition.

Tigay, J. You Shall Have No Other Gods. Israelite Religion in the Light of Hebrew Inscriptions. Atlanta, GA: Scholars Press, 1986.

van der Toorn, K. Dictionary of Deities and Demons in the Bible. Leiden: Brill, 1995.

. "Theology, Priests, and Worship in Canaan and Ancient Israel". Civilizations of the Ancient Near East. Two volumes. Edited by J. M. Sasson. New York, NY: Scribner, 1995, 2:2043-58.

. "Nine Months Among the Peasants in the Palestinian Highlands: An Anthropological on Local Religion in the Early Bronze Age". Symbiosis, Symbolism, and the Power of the Past. Edited by W. G. Dever. Indiana, IN: Eisenbrauns, 2003, 393-410.

Viviano, P. "Ethbaal". The Anchor Bible Dictionary. New York, NY: Doubleday, 1922, 2:645.

von Soden, W. The Ancient Orient. Grand Rapids, MI: Eerdmans, 1985.

Vriezen, J. H. Palestinian Inscriptions. Leiden: Brill, 1951.

Walton, J. Ancient Israelite Culture in Its Ancient Context. Grand Rapids, MI: Zondervan, 1990.

Wyatt, N. "Astarte". Dictionary of Deities and Demons in the Bible. Second edition. Edited by K. van der Toorn. Grand Rapids, MI: Eerdmans, 1999, 109-114.

Zevit, Z. The Religions of Ancient Israel. New York, NY: Continuum, 2001. 